\title{
すべり摩擦時に発生するアコースティックエミッションに 及ぼす極薄潤滑膜の影響*
}

\author{
田浦 裕 生*1, 高木聡彦*2, 川口雅弘*3

\section{Effect of Ultrathin Lubricant Films on Acoustic Emission Generated by Sliding Friction} \\ Hiroo TAURA*5, Toshihiko TAKAKI, Masahiro KAWAGUCHI, \\ Satoru KANEKO and Takahisa KATO \\ ${ }^{* 5}$ Faculty of Engineering, Nagaoka University of Technology, \\ 1603 1 Kamitokioka-machi, Nagaoka-shi, Niigata, 940-2188 Japan
} 金子覚 ${ }^{* 1}$, 加藤 孝 久*4

\begin{abstract}
This paper shows the effect of ultrathin lubricant films between sliding bodies on acoustic emission ( $\mathrm{AE}$ ) signals induced by the sliding friction and discusses the application of the $\mathrm{AE}$ techniques to the monitoring of the lubricant films. Experiments were conducted with a ball-on-disk friction tester to measure the AE signals. The ball was a glass ball of $5 \mathrm{~mm}$ diameter. The disk was a magnetic disk with a DLC protective layer on its surface, and was coated with PFPE Z-dol 4000 about $1.5 \mathrm{~nm}$ thick. The noticeable $\mathrm{AE}$ envelope signals were induced by the local decrease in the mobile layer at the initial stage of the friction test, and then the magnitude of AE envelope signals increased with the decrease of both the mobile and the bonded layers. The AE map, which is a cascade graph of the $\mathrm{AE}$ envelope signals measured in time order, was proposed to monitor the time variation of the spatial distribution of PFPE film thickness, and showed that the mobile layer moved to the direction of friction.
\end{abstract}

Key Words : Tribology, Friction, Acoustic Emission, Perfluoropolyether, Ultrathin Lubrinant Film

\section{1. 蝫}

アコースティックエミッション（AE, acousic emission）は，固体が变形，破壊する際にそれまで蓄積 されたひずみエネルギーが解放されることにより生じ る弾性波で、工学的な有用性から多くの分野で利用 されている. 摩擦などによっても生じることから、ト ライボロジーの分野でも研究が進められ，摩察・摩耗 との関連性务明らかにされてきた. 近年では，微 小な接触の検知が可能であることや応答性の良さ等を 活かし，磁気ディスク装置におけるへッドとディスク の接触の検知の) や、ヘッドの浮上是推定，ヘッドの 摩耗量推定けよ゙，程栖的に応用されている. AEは固 体同士の接螌によって発生することから潤滑状態に影 敕されることはいうまでもないが，上記論文では，固

* 原稿受付 2005 年 6 月 20 日.

*1 正員. 長岡技術科学大学工学部( 840 -2188 長岡市上富岡 町 1603-1).

*2 ソニーセミコンダクタ九州(株) ( 899-4393 国分市野口北 51 ).

*3 東京大学大学院工学系研究科( - 113-8656 東京都文京区本 郷 7-3-1)

*4 正員, 東京大学大学院工学系研究科

E- mail : htaura @ mech.nagaokaut.ac.jp
体間に存在するごく薄い濉滑膜の影響，とりわけ固体 表面に吸着した潤滑剤がどのような影御を与えるかれ ついて，十分に考虑されてきたとは言えない，

著者ら 用いて, PFPE (Peffurapotyeher) を薄く一様な厚さで 㳂布したディスクを摩摽した際，ある試敄時間以降デ イスクの一部分で AE 信号の振幅が増加し，さらに時 問とともに振幅が増加した部分が周方向に搪大するこ とを明らかれした. この $\mathrm{AE}$ 信号の振幅の変化は, 潤 滑膜㫗の堿少に起因すると推測されるものの，発生し た AE 信号と潤滑膜㫗との対応は現在のところ明らか ではない.

本稿では，AE 信号におよぼす澊滑膜の影郎を明ら かにすへく，摩察試験中に測定された $\mathrm{AE}$ 信号と訊験 停止直後に測定した膜㚖を比較した結果を報告する.

\section{2. 实族}

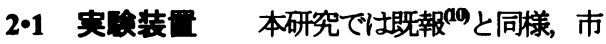
販のボール・オン・ディスク型摩擦試験機（㑣レスカ 製FRP-2000）を用い，これにAE測定装置を組付けて 
使用した. ボールは，直径 $5 \mathrm{~mm}$ 、材質 BK 7 のガラス 球, ディスクは, 25inchのハードディスク (DLC保護 膜 $5 \mathrm{~mm}$ 傢性膜/゙ラス基板 $\mathrm{Ra} 0.8 \mathrm{~nm}$ ) であり, ディスク には潤滑剤を塗布している.

図 1に, $\mathrm{AE}$ 信号の測定系の概略を示す。AEセンサ (NF 回路ブロック社製 $\mathrm{AE}-903 \mathrm{~N})$ は，ボール保持部 の外面に接着した. その出力は, プリアンプ ( $\mathrm{NF}$ 回 路ブロック社製 AE-912)，ディスクリミネータ（NF 回路ブロック社製 $\mathrm{AE}-922)$ により増幅，包絡線処理 された後，AD変換器に入力され集録される. また, ディスクリミネータを出た後の信号は, デジタルオシ ロスコープにも入力され，リアルタイムで信号波形が 観測される. AE 信号の集録は，ディスクに取り付け た遮光板がフォトインタラプタを通過する瞬間に発生 するパルス信号を集録開始のトリガ信号として用いた。 サンプリング周波数は $10 \mathrm{kHz}$ ，サンプリング点数は 2 048 点, これを 1 回のサンプリングとし，1から5秒間 隔で実験終了まで繰り返し集録を行った。

$2 \cdot 2$ ディスク 本実験では，潤滑剤を一様な厚 さに塗布したディスクを適当な時間摩擦した後, 潤滑 膜㝵を測定し，摩擦を停止する直前に測定された $\mathrm{AE}$ 信号と比較を行う．使用した潤滑阂は，PFPEZdoH000 (分画処理済み) で，約 $1 \mathrm{~nm}$ の厚さになるようディ スクに塗布する.ここで，潤洞膜の厚さが数 $\mathrm{nm}$ と分 子レベルであることから，固体表面に化学吸着した分 子 (固定層) と，それ以外の分子 (流動層) とを区別 する必要が出てくる(1)ため，以下では潤滑膜の総膜厚 に加えて，固定層膜厚も記すものとする，なお，潤滑 剤の塗布はディップ法を用いており，その後で固定層 を厚化するために，加熱処理を加えている. また，比 較のため，加熱処理後にリンス処理を施して流動層を 除去したディスクでも実験を行った.

潤滑膜厚は，反射型エリプソメータ（Frvelab社製 MARY-102）を使用し，摩擦トラックの周りを周方向 に 2 間隔で 180 点，半径方向に $0.1 \mathrm{~mm}$ 間隔で 5 点 測定した. 測定の詳細は文献 12)に記す通りである. 測定に際して必要となる潤滑膜の屈折率およひ吸収率 はそれぞれ 1298，0，ディスクの屈折率およひ吸収率 は潤滑剤を塗布する前にディスクの広範囲をあらかじ め測定し，その平均值を用いた. 潤滑膜厚の測定精度 は土0.5nmで，これは本来ディスク面上で分布を持つ ディスクの届折率およひ吸收率を一様であるとし，そ の平均値を用いたために生じる誤差の影響が大きい． そのため，次章で述べるように周方向に膜厚分布の定 性的な変化を見る際には，さらに高い精度て膜厚の変 化を捉えられるものと考えられる.

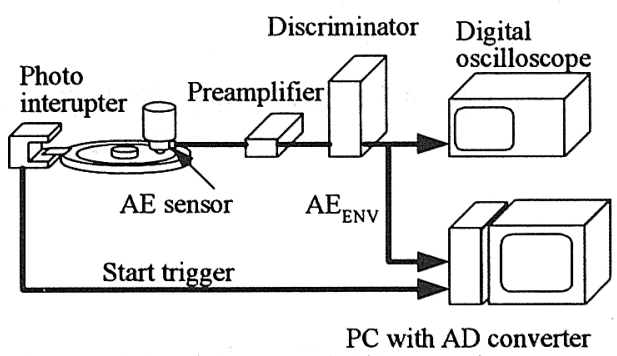

Fig.1 Schematic of AE measurement system

$2 \cdot 3$ 実験条件 全ての実験は, 荷重 $0.98 \mathrm{~N}, テ ゙$ イスク回転速度 $200 \mathrm{pm}$ ，ボールと接触するディスクの 半径は $24 \mathrm{~mm}$ とし, 大気圧, 室温下で行った.

\section{3. 実験結果}

図 2 に今回の実験て測定された摩擦係数と $\mathrm{AE}$ 実 効值の時間変化の一一例を示す. 既報《10で報告されて いるものと定性的に一致した結果であり, 図中の点線 部分で摩擦係数と $\mathrm{AE}$ 実効值の傾向が変化しており, この時点を境に「流動層の摩耗を主とした領域」から 「固定層の摩耗を主とした領域」に遷移した(12) と考え られる. 遷移前の「流動層の摩耗を主とした領域」で は， $\mathrm{AE}$ 信号はディスク周方向に一様である(10ため, 以下では，「固定層の摩耗を主とした領域」に遷移し た直後（図中の A 付近），および A から数十秒経過 した時点（図中の B 付近），さらに十分な摩擦時間 が経過して摩擦釈数が非常に大きな振幅で振動した時 点（図中の C) の三䇫所で摩察実験を停止させて $\mathrm{AE}$ 包絡線信号と潤滑膜の周方向膜厚分布を比較する. な お，実験中断の影響を避けるため A から C の点では， 潤滑剂を同時に塗布した異なるディスクを用いた。

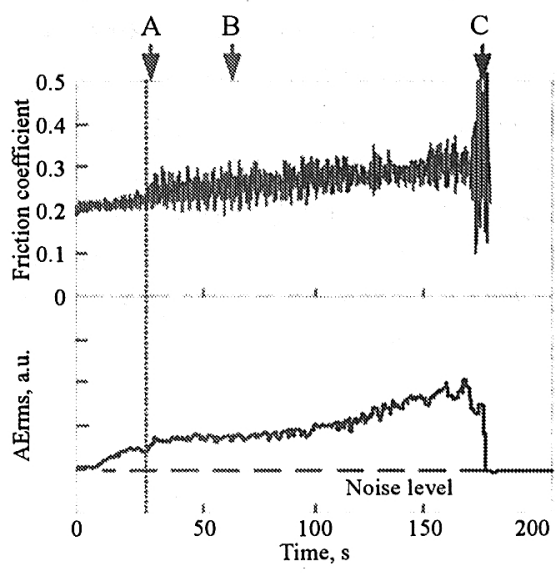

Fig.2 Typical time variation of Friction coefficient 
図2のAの付近で実験を停止した場合の結果を図 3 に示す. 図 3(a)は実験停止直前で測定された $\mathrm{AE}$ 包絡 線信号，図 3(b)䐏験停止直後に測定した潤滑莫の周 方向膜皋分布である. 横蚰はディスクの回転角を表し ており，摩擦方向はディスクの回転角の大きな方向で ある. 図 3(b)では, ボールが摩察したトラックにおけ る膜厚を実線，それと比較する目的で摩察していない トラックにおける膜量を破線で示す，さらに潤滑膜の 総膜厚を太線，固定層膜㝵を細線で示す.

図 3(a)の AE包絡線信号は大部分では一定值で推 移しているものの, $210^{\circ}$ と $260^{\circ}$ を心とした二筒所 に小さなピークが見られる. 図3(b)の膜厚分布を見 ると, $210^{\circ}$ と $260^{\circ}$ 付近を除けば実験前に比べて総膜 厚, 固定層膜厚とも全体的に若干の堿少が見られる のみで，実験前に比べて局所的に大きく減少してい る部分は見られない. 一方, $210^{\circ}$ と $260^{\circ}$ 中心とし た部分では，固定層膜厚は他の場所での值に比べて 大きな変化が見られないものの, 総膜厚については 他の部分よりも明らかな减少が見られ，主として流 動層膜厚が堿少していることが分かる. この結果よ り, 流動層膜厚の減少に対応し, $\mathrm{AE}$ 包絡線信号の レベルが増加したものと推測される.

続いて, 図 2 の B 付近での結果を図4に示す. 図

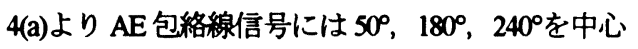
とした三箇所に明らかなピークが見られ，前二つは

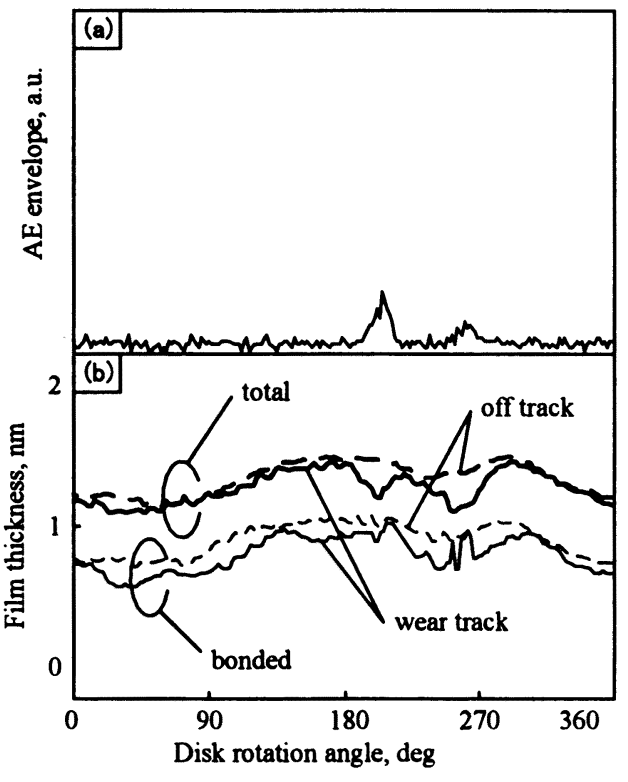

Fig3 3 Comparison between $\mathrm{AE}$ envelope signal and hubricant film thickness distribution at point A shown in Fig 2
最後のものに比べてピークが高くなっている. 図 4(b)より，上記ピーク位置における潤滑膜厚を見て いくと，まず低いピークの見られる 240 付近では, 総膜厚の低下が見られるものの, 固定層膜厚の変化 が小さなことから, 主に流動層膜厚が低下している ことが分かる. これは図 3 の $210^{\circ}$ と $260^{\circ}$ で見られた 結果と同様と考えられる. 一方, AE包絡線信号で 高いピークが見られる $50^{\circ}, 180^{\circ}$ 付近の潤滑膜厚を 見ると, 総膜厚は $50^{\circ}$ では大きな変化はないのに対 し，180では大きく減少しているという違いがある. しかし, 両者とも固定層膜厚が明らかに减少してい ることが分かり， $\mathrm{AE}$ 包絡線信号の上昇が固定層膜 厚の減少に対応していると考えられる.また， $330^{\circ}$ を中心とした部分では, $\mathrm{AE}$ 包絡線信号は低い にも関わらず, 総膜厚, 固定層膜厚とも大きく減少 している結果が得られている.

最後に図 2 のC付近での結果を図5に示す. 図 5(a)の AE 包絡線信号は, 全体的には図 3(a)P図 4(a) と比べて大きな値を示しているものの，900，300 を中心とした二箇所での值が他の部分に比べて明ら かに小さくなっている. 図 5(b)の潤滑膜厚を見ると， 固定層はディスクのほぼ全域で見られないものの, 総膜厚は $\mathrm{AE}$ 包絡線信号が比較的に小さな $90^{\circ}$ を中 心とした部分で見られることから，この部分では流 動層が存在していることが分かる. 300付近でも

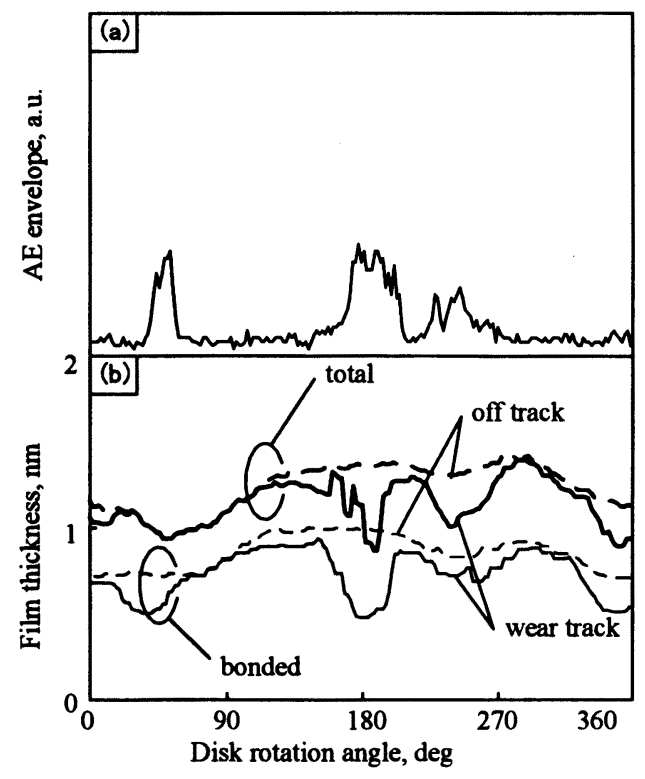

Fig 4 Comparisan between $\mathrm{AE}$ envelope signal and hubricant film thickness distribution at point $B$ shown in Fig 2 
$90^{\circ}$ 付近と比べれば小さいものの, 潤滑膜の存在が 確認できる.これから，比較的低いAE包絡線信号 となる領域は，流動層の存在する部分と対応してい ることが分かる.

以上の結果から，AE包絡線信号と潤滑膜厚とに 対応関係が見られることが明らかとなった. 具体的 には，その出力がノイズレベルである場合には，十 分な膜厚の流動層が存在する. 若干の出力の上昇が あれば流動層膜厚が減少した状態に対応し，さらに 出力が増加すると固定層膜厚が減少していることを 示していると考えられる. ただし，図 4 の $330^{\circ}$ 付 近のように膜厚が低下しているにもかかわらず $\mathrm{AE}$ 包絡線信号の出力が小さな部分や，図 4 の $50^{\circ}$ 付 近のように十分な流動層があるにもかかわらず，固 定層膜厚が减少し AE包絡線信号に比較的大きなピ 一クがみられるなど，十分説明できない点も見られ る.これらの原因については, 現在のところボール に付着した潤滑剤の影響が大きいと考えているが， 詳細は明らかでなく，さらに検討する必要がある.

図 5 の $90^{\circ}$ 付近では, 固定層がほぼなくなって いるにもかかわらず，流動層が存在する結果となっ た. 流動層が存在するにもかかからず，より強固に 固体表面に吸着したと考えられる固定層のみが減少 することは考えにくいことから，流動層，固定層の 順に潤滑膜が減少した後に流動層が外部から流入し

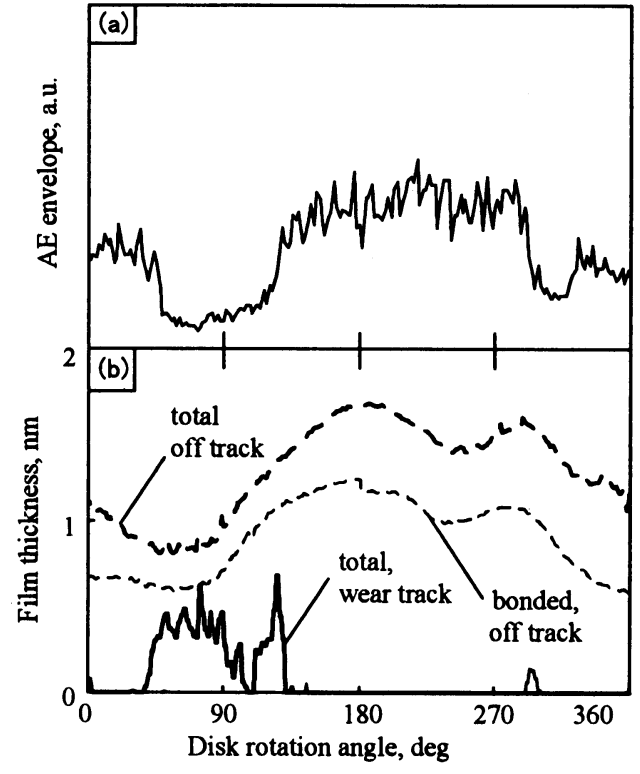

Fig.5Comparison between $\mathrm{AE}$ envelope signal and lubricant film thickness distribution at point $\mathrm{C}$ shown in Fig 2
膜厚を回復したと考えるのが妥当である.この点か ら，潤滑膜の减少過程の把握には，膜厚の時間的な 変化を知ることが必要であると考えられる.

\section{4. 考家}

前章の実検結果から，AE包絡線信号はディスク 上の局所的な膜厚に対応してその值が変化している ことが明らかとなった。このことから，润洞膜厚を 直接測定しなくても， $\mathrm{AE}$ を用いて空問的な䐉厚分 布がある程度把握可能であると考えられる．さらに 直接的な膜厚測定と比心゙， $\mathrm{AE}$ 測定の摩擦実験を中 断することなく高速でデータを取得可能という特長 を利用すれば，潤滑膜基の時間的変化および空間的 変化がより詳細に調べられる可能性が見いだされる.

そこで, 繰返し摩摽の際に得られる摩察力の時間 的，空問的な变化を調べた福田の研究 ${ }^{(3)}$ を参考にし， 図 5 の結果を得るまでに取得した AE 包絡線信号を 時間順に重ね合わせて，AE包絡線信号の時問的， 空間的な変化を視覚化したグラフ (以下，AEマッ ブ）を作成し，図6に示す. 横軸はディスク回転角 であり，AE包絡線信号は時問が新しいものほど上 になるように表示してある. 摩擦方向は左から右で ある. なお，前述の通り，図5は図 $3 ， 4$ と異なる ディスクを用いた結果であるため，閵滑郕の堿少し た位置，進行状況は後者と若干異なるものとなる。

図6を見ると，実験開始後ディスク全面で低い值 を示していた $\mathrm{AE}$ 包絡線信号は，ほほ同時期に $45^{\circ}$ ， $110^{\circ} ， 240^{\circ} ， 270^{\circ}$ の四筒所でピークが現れ，時 間とともにその幅を扗大しながら摩徖方向に移動し ていく，さらに時間が経過すると，周方向位置が変 化しない，より高いピークが現れる.

上記結果と比較するため，潤滑刘を固定層のみと したディスクでの AEマップを図7に示寸．実験初 期では AE包絡線信号はディスク周方向にほほ一様 の高さとなっているのに対し，実験時問が経過する とディスクの特定の部分で高いピークが現れるよう になる.このピークは-一定の位置で発生し続けてお り，図6の実験後期に見られたピークと同じ傾向を 示している.

図6を図 7 と比較すると， $\mathrm{AE}$ 包絡線信号のピー クが摩擦方向に移動する点で大きく異なっており， この相違は流動層の存在に起因しているものと考え られる. 図6における AE 包絡線信号のピークの摩 擦方向一の移動は，流動層が摩擦方向の上流から下 流八向かい移動していることを表していると考えら れる．一方図7では， $\mathrm{AE}$ 包絡線信号のピークが摩 


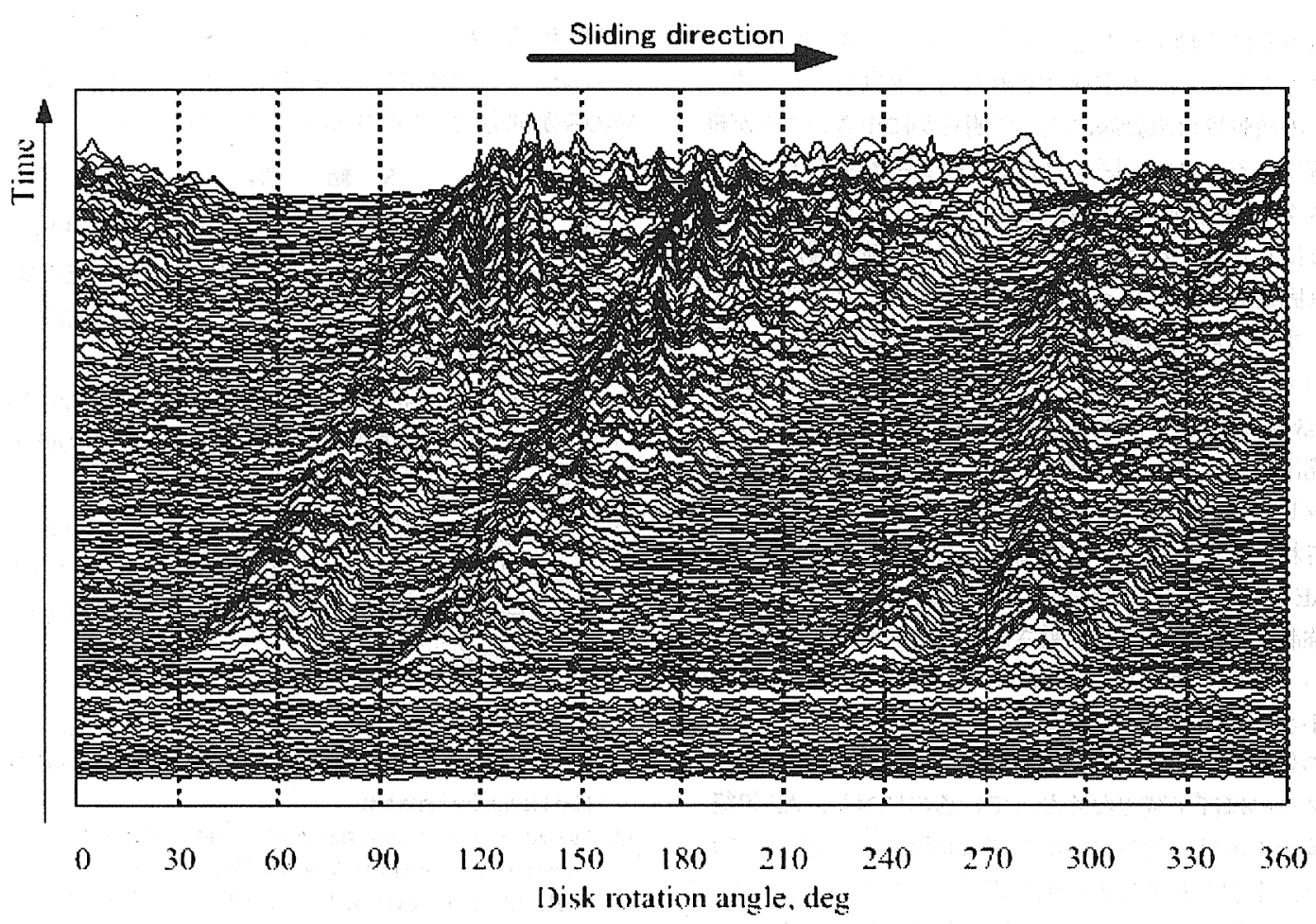

Fig.6 Cascade graph of AE envelope signals for the disk shown in Fig. 5

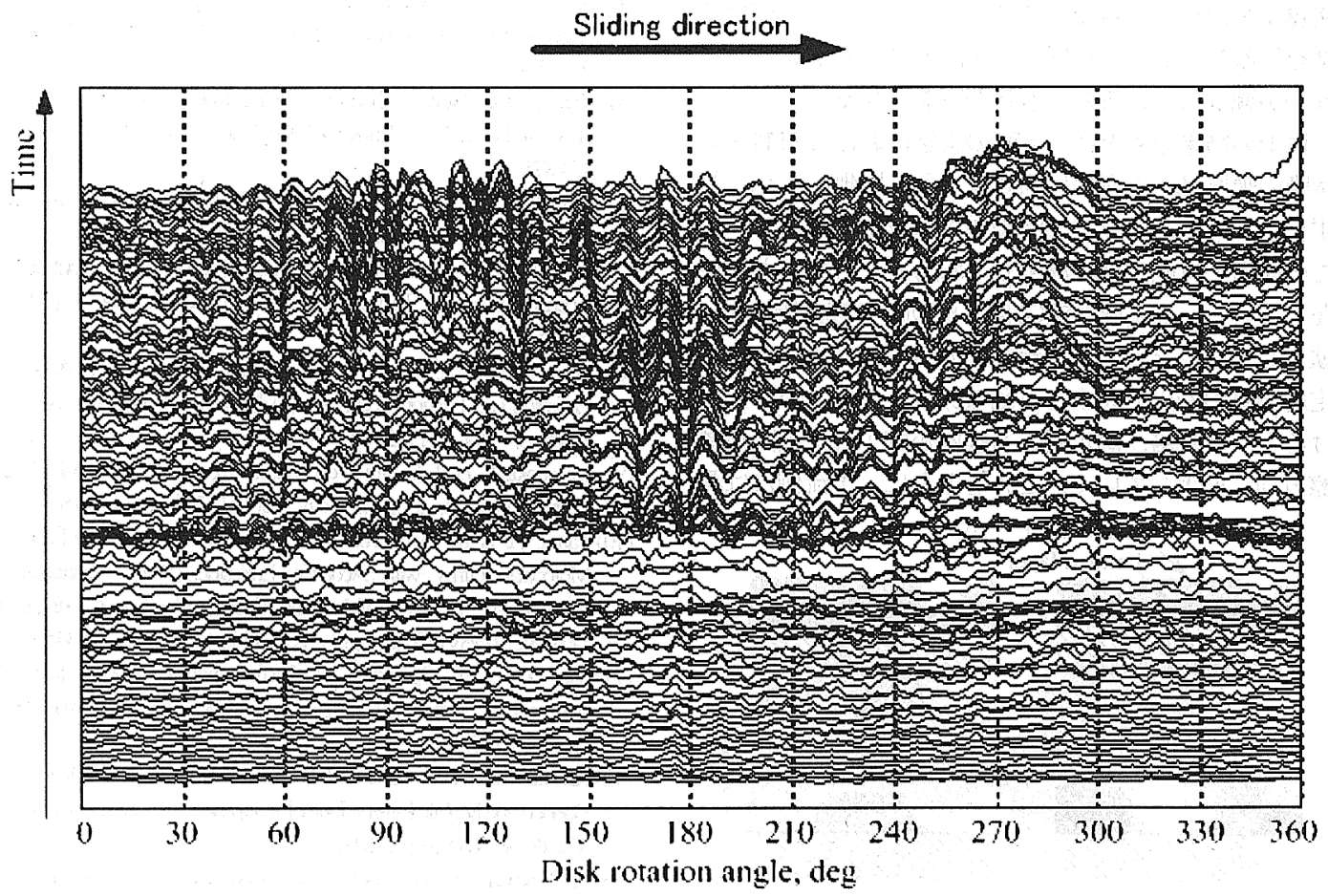

Fig7 Cascade graph of $\mathrm{AE}$ envelope signals for the disk with bonded films. 
擦方向に移動することはなく，一定の位置で発生し続 けることから，固定層は摩擦方向に流動しておらず， その流動性は流動層に比べて明らか水小さいことが理 解できる. また，図6でもある程度摩擦すると，ディ スクの特定の位置で発生し続けるピークが見られるよ うになる.これは、ピーク発生部分の流動層が除去さ れ固定層のみとなったことを表していると考えられる。 また, $\mathrm{AE}$ 包絡線信号の摩擦方向への移動を，一定 のディスク位置 (例えば図 6 の $60^{\circ}$ ) で見ると， $\mathrm{AE}$ 包絡線信号が一旦増加した後に低下することになる。 潤滑膜の状態としては，流動層，続いて，固定層が減 少した後に，外部から潤滑剤が供給され流動層が修復 されたと考えられる. 供給された潤滑剤については, $\mathrm{AE}$ マップ全体の傾向とあわせると，ボールによって 強制的に摩擦方向一移動させられた流動層が主体とな っており，摩擦方向に垂直な方向からの流入の影響は 小さいものと考えられる. 先に示した図5(b)は，図6 の最後の状態における膜厚分布である. 固定層がディ スクのほぼ全域でなくなっているのに対し， $\mathrm{AE}$ 包絡 線出力の低い 部分に対応して流動層が厚く存在してお り，上記の潤滑膜の修復作用が確認できる。このこと から，修復作用のある潤滑膜の状態を理解するには， 限定された瞬間における情報だけでは限界があり，時 間履歷を含めて知らなくてはならない，また，時間履 歴を知ることができれば, 現在流動層, 固定層のいず れかが減少しているのかも判別可能となる.

以上の結果をもとに，今回の実験における PFPE潤 滑膜の膜厚減少の過程は図8のように推測される.ま ずディスクのある位置で流動層が減少する(図 8(a)). この段階では固定層は減少しておらず十分な厚さで存 在している. その後摩擦方向に流動層の減少領域が 拡大していくとともに, 流動層の膜厚が低下により固 定層膜厚の減少が始まる (図 8(b)) 。さらに摩擦を続 けると，流動層，固定層とも膜厚が減少した範囲が摩 擦方向に拡大していく.これとともに，上流側には潤
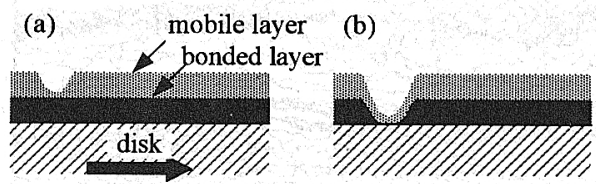

(c)

(d)
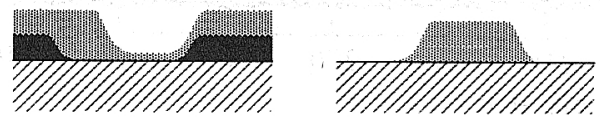

Fig.8Wear process of Lubricant film
滑剤が供給され，一度無くなった流動層が回復する (図 8(c))．最終的には固定層はほぼなくなり, 流動 層のみが部分的に存在するようになる(図 8(d)).

\section{5. 結 論}

ボール・オン・ディスク型摩擦試験機を用いて PFPE 潤滑膜を塗布したディスクを摩擦した際に得られる $\mathrm{AE}$ 包絡線信号と，対応する潤滑募厚の関係を調べた結果， 以下の知見が得られた。

1. $\mathrm{AE}$ 包絡線信号の出力は, ディスクの局所的な流動 層, 固定層の膜厚と相関関係があり, 膜厚の低下 により増品る。

2. 摩擦開始から終わりまでの間に測定した $\mathrm{AE}$ 包絡線 信号を順番に重ね合わせて作成した $\mathrm{AE}$ マップを用 いれば，潤滑膜の時間的，空間的な変化の把握が 可能となる.

\section{文 献}

(1) Isono, E et al, Acoustic Emission, (1990), The Japanese Society for Non-Destructive Inspection.

(2) Lingard, S. et al, An Investigation of Acoustic Emission in Sliding Friction and Wear of Metals, Wear, Vol. 130,(1989), pp.367-379.

(3) Wada, M et al, Study on Friction and Wear Utilizing Acoustic Emission, Joumal of the Japan Society of Procision Engineering Vol 55,No. 4(1989), pp.673-678.

(4) Jiaa, C.L et al, Experimental Studies of Sliding Friction and Wear via Acoustic Emission Signal Analysiş, Wear, Vol 139, No. 2(1990), pp.403-424.

(5) Kita, T. et al, New Method of Detecting Contact Between FloatingHead And Disk, EEEE Trans. OnMag Vol MAG-16, No.5(1980) pp. 873-875.

(6) Khurshudov, A et al, Head-Disk Contact Detection in the Hard-Disk Drives, Wear, Vol255,(2003), pp.13141322.

(7) Jiaa, CL. et al, Evaluation of HeadDisk Pseudo-Impact Contact by Acoustic Emission Techniques, Tribology Letters, Vol. 3, (1997), pp.165-174.

(8) Gitis, N.V. et al, Study of Low Flying Height Using Acoustic Emission and Friction Techniques, Advances in Information Storage Systems, Vol.6,(1995) pp.107-120.

(9) Matsuoka, K et al, In-Situ Wear Monitoring of Slider and Disk Using Acoustic Emission, J. of Tribology, Vol.123, (2001), pp.175-180.

(10) Taura, $\mathrm{H}$ et al, An Observation of Wear Process of Bi-Layerod Molecular Films with Acoustic Emission (Part 1)-Relationship between AE Effective Value and Friction Coefficient-Joumal of Japanese Society of Tribologists, Vol 50, No.4(2004), pp.338-345.

(11) Ma X at al, Spreading of Perfluoropolyalkylether Films on Amorphous Carbon Surfaces, J.ChemPhys., Vol.110, No.6(1999), pp.3129-3137.

(12) Kawaguchi, M a al, Durability of PFPE Lubricant Films with Bonded and Mobile Layers, Joumal of Japanese Society of Tribologists, Vol.48, No.5(2003), pp.410-417.

(13) K Fukuda, Friction Force Distribution and Its Altemation with Repeated Sliding Joumal of Japanese Society of Tribologists, Vol43, No. 9(1993) pp.788-795 